\title{
Correlation between Tail Length and Rate of Infected Quarters in Montbéliarde and Ameliorated Dairy Cattle, Algeria
}

\author{
Mammeri Adel ${ }^{1,2 *}$, Kayoueche Fatima Zohra ${ }^{1}$, Benmakhlouf Abdelmalek ${ }^{1}$ and Retima Zahira ${ }^{3}$ \\ ${ }^{1}$ Animals Pathology and Reproduction Control Laboratory (P.A.G.R), Veterinary Institute, University of Constantine, Algeria \\ ${ }^{2}$ Department of Agronomic Sciences, University of M'Sila, Algeria \\ ${ }^{3}$ Department of Nature and Life Sciences, University of Biskra, Algeria
}

Submission: May 17, 2019; Published: June 19, 2019

*Corresponding author: Mammeri Adel, Department of Agronomic Sciences, M'Sila University, Chaâbane Abd Hafidh Avenue, M'Salah City, Biskra 07000, Algeria

\begin{abstract}
This study aimed to evaluate the impact of the tail's length of Modern Dairy Cattle and Ameliorated Dairy Cattle on the rate of infected quarters.12 lactating cows were randomly selected; 6 breed Montbéliarde and 6 Ameliorated Dairy Cattle, subsequently the distance between the tail edge and the ground was measured with a tapeline. Then, California Mastitis Test was realized on milk samples collected from the 4 teats of each cow. Spearman test $(\mathrm{p}<0.01)$ showed that contamination risks of teats surface via the cow's tail, were associated to Ameliorated Dairy Cattle breeding and environmental hygiene level (litter).
\end{abstract}

Keywords: Tail length; Cattle genotype; Mastitis; Tank contamination; Algeria

\section{Introduction}

Several studies showed that genetic selection affects the harmony of the compliance of the body (especially the hip height) [1]. The cows breed Montbéliarde (Mt) are among the most imported Modern Dairy Cattle (MDC) cows in Algeria. Also, according to skin color, the Ameliorated Dairy Cattle (ADC) cows include two dominant types; ADC-Pie Rouge (ADC- PR) and ADC-Pie Noire (ADC- PN). ADC cows are the result of several crossbreeds between the Algerian local cattle populations and the MDC breeds [2]. In Algeria, crossbreeding operations are mainly made by unqualified breeders, affecting thus the general harmony of different body parts of progeny. The cow's tail is one of these affected parts, being consequently of variable length that is not always correlated to hip height, additionally to be among the most moving organs and exposed to various environmental contaminants, in simultaneity of being relatively promiscuous to the surface of the teats. Accordingly, tail length should be considered as a principal factor of variability in rates of infection of the udder. This comparative study aimed to evaluate and compare the impact of tail length and cattle category, on the California Mastitis Test (CMT) positivity rate and the number of infected quarters in Mt and ADC cows.

\section{Materials and Methods}

We visited 3 dairy cattle farms, located in the region of Doucen (governorate of Biskra). All herds had similar hygienic profiles. From lactating cows, we randomly chosen 6 Mt, 5 ADC- PR and one ADC- PN, then the distance between the end edge of the tail and the surface on the ground (DTG) was measured with a tapeline. After that, we realized a CMT test on milk samples collected from the 4 teats of each cow. CMT reaction was numbered from 0 to 4. The relationship between the number of cells and the score of CMT, was approximately established from the results of Schalm and Noorlander [3] and Schneider [4]. The quarters with a score $\geq 2$, was considered infected. The quarters with score ranging from 0 to 1, are classified uninfected. Statistical analysis via SPSS version 20. [5], included Spearman test $(p<0.01)$ between the variable cow category (MDC /ADC) and the variable DTG.

\section{Results and Discussion}

Results showed that all Mt cows $(\mathrm{n}=6)$ had DTG $\geq 15 \mathrm{~cm}$, whereas (5/6) of ADC cows had DTG $\leq 15 \mathrm{~cm}$. The DTG showed an average value $(21.33 \pm 5.77 \mathrm{~cm})$ for the Mt cows, and $(10.17$ $\pm 8.22 \mathrm{~cm}$ ) for the ADC cows. The minimum values of DTG were 
recorded for the cows coded; ADC-PN-8 (00 cm), ADC-PN-12 $(04 \mathrm{~cm})$, ADC-PR-7 $(05 \mathrm{~cm})$ and ADC-PN-10 (07cm) (Table 1). Statistical analysis via SPSS version 20. (IBM, 2011), using Spearman test $(\mathrm{p}<0.01)$ between the variable cow category (MDC /ADC) and the variable DTG, was highly significant ( $\mathrm{p}=0.001)$. Also, (2/6) of Mt cows had at least one of the posterior quarters Table 1: Distribution of DTG and CMT positive quarters per cow. that is infected, whereas (4/6) of ADC cows had at least one of the posterior quarters that is infected. Only (1/6) of Mt cows, had two posterior quarters that were simultaneously infected, in opposition to $(3 / 6)$ of the ADC cows with two quarters that were simultaneously infected (Table 1).

\begin{tabular}{|c|c|c|c|c|c|c|c|c|c|c|c|c|}
\hline Herd's Code & \multicolumn{6}{|c|}{ (A) } & \multicolumn{4}{|c|}{ (B) } & \multicolumn{2}{|c|}{ (C) } \\
\hline Cow's Category & & & MD & & & & & & & DC & & \\
\hline Cow's Code & Mt-1 & Mt-2 & Mt-3 & Mt-4 & Mt-5 & Mt-6 & PR- 7 & PN-8 & -PN-9 & PN-10 & PN-11 & PN-12 \\
\hline DTG (cm) & 35 & 17 & 16 & 15 & 20 & 25 & 05 & $\mathbf{0}$ & 15 & 07 & 30 & 04 \\
\hline CMT positive quarters & 0 & $\begin{array}{c}1 \\
\mathrm{PL}\end{array}$ & 0 & 0 & 0 & 4 & $\begin{array}{c}3 \\
\text { AR } \\
\text { PR } \\
\text { PL }\end{array}$ & 0 & 0 & 4 & $\begin{array}{c}3 \\
\text { AL } \\
\text { PR } \\
\text { PL }\end{array}$ & $\begin{array}{c}1 \\
\text { PL }\end{array}$ \\
\hline
\end{tabular}

MDC: Modern Dairy Cattle; ADC: Ameliorated Dairy Cattle; Mt: Montbéliadre; PN: Pie Noire; PR: Pie Rouge; DTG: distance between the end edge of the tail and the surface on the ground; PL: Posterior Left; PR: Posterior Right; AL: Anterior Left; AR: Anterior Right.

About 96\% of Algerian farmers hold a herd of less than 6 dairy cows [6]. Relatively small dairy ADC herds (1- 6 cows), are located in mountainous and forest areas, and are the result of multiple crossbreeds between the local population, primarily the Brune de l'Atlas and the imported breeds [7]. In these herds, mechanical milking, is generally reserved to herds inserted into a milk collection organisms, however, hand milking is dominantly practiced in the rest of the herds. Thus, the contamination risks of milking vessel content during milking, on one hand, and the surface of the teats, on the other hand, via the cow's tail, seem to be associated to DTG and environmental hygiene level (litter). These risks are amplified by the fact that in Algeria, a very small part of ADC cow's milk is collected, but dairy products are mainly oriented, in the raw status, to self-consumption, donation and feeding calves [8]. Also, zoonotic and abortive risks cannot be excluded in such circumstances $[9,10]$.

\section{Conclusion}

It is urgent to avoid the generalization of the ADC category, without considering the influence of cattle anarchic crossbreeding on the welfare of future progeny, on susceptibility to infections of cow's mammary glands and thus the safety of their milk. Therefore, it is suitable to adapt the dairy cow's genotype to dominant cattle breeding system. Crossbreeding operations and genetic selection should be exclusively accomplished by qualified personnel but not unwary breeders.

\section{Conflict of interest}

The authors declare that they have no conflict of interest.

\section{References}

1. Fadock VA (1984) Parasitic skin diseases of large animals. Vet Clinic North Am 6: 3-26.

2. Soulsby EJ (1982) Helminthes, Arthropods, and Protozoa of Domestic Animals. (6 ${ }^{\text {th }}$ edn), Bailliere Tin Dall, London, UK, pp. 323-327.
3. El Bihari S (1985) Helminths of the camel: a review. Br Vet J 141: 315326.

4. Schillhorn Van Veen TW, Bello SI, Folaranmi DO (1976) Onchocerca armillata (Railliet and Henry, 1909) from a new host, Camelus dromedari. Rev Elev Med Vet Pays Trop 29: 227-228.

5. Nasher AK (1986) Incidence and intensity of Onchocerca fasciata (Railliet and Henry, 1910) in local camels in Saudi Arabia. Ann Parasitol Hum Comp 61: 77-80.

6. Awad MA, Osheik AA, Tageldin MH, Zakiam AM (1990) Note on Onchocerca armillata in the Sudanese camel (C. dromedarius). A histological and anatomo-pathological approach. Rev Elev Med Vet Pays Trop 43: 345-348.

7. El-Massry AA, Derbala AA (2000) Evidence of Onchocerca fasciata (Filarioidea: Onchocercidae) in camels (Camelus dromedarius): I-prevalence, nodular lesions appearance and parasite morphology. Vet Parasitol 88: 305-312.

8. Ghandour AM, Al-Amoudi AA (1991) Onchocerca fasciata and its nodule development in camels in Saudi Arabia. Vet Parasitol 39: 67-77.

9. Holdsworth PA, Moorhouse DE (1985) Onchocerca gutturosa in an Australian camel. Aust Vet J 62: 201-202.

10. Hussein HS, el Mannan AM, el Sinnary K (1988) Onchocerca armillata (Railliet and Henry, 1909) and Onchocerca gutturosa (Neumann, 1910) in camels (Camelus dromedarius) in the Sudan. Vet Res Commun 12: 475-480.

11. McFrederick QS, Haselkorn TS, Verocai GG, Jaenike J (2013) Cryptic Onchocerca species infecting North American cervids, with implications for the evolutionary history of host associations in Onchocerca. Parasitology 140: 1201-1210.

12. Murdoch ME, Hay RJ, Mackenzie CD, Williams JF, Ghalib HW, et al. (1993) A clinical classification and grading system of the cutaneous changes in onchocerciasis. Br J Dermatol 129: 260-269.

13. El-Bahnasawy MM, Morsy AT, Morsy TA (2015) The arthropod-borne onchoceriasis: is it deserved to be neglected? J Egypt Soc Parasitol 45: 639-654.

14. Ali MM, Baraka OZ, AbdelRahman SI, Sulaiman SM, Williams JF, et al. (2003) Immune responses directed against microfilariae correlate with severity of clinical onchodermatitis and treatment history. J Infectious Dis 187: 714-717. 
15. Abdul-Salam J, Al-Taqui M (1995) Seasonal prevalence of Onchocer$c a$-like microfilaria in camels in Kuwait. Journal of Egyptian Society of Parasitology 25: 9-24.

16. Cheema AH, El-Bihari S, Ashour NA, Ali SS (1984) Onchocerciasis in camels (Camelus dromedarius) in Saudi Arabia. J Helminthology 58: 279-285.

This work is licensed under Creative Commons Attribution 4.0 License

DOI: $10.19080 / J D V S .2019 .12 .555843$
17. El Sinnary K, Hussein HS (1982) Onchocerca gutturosa (Neumann), in camels (Camelus dromedaries) in the Sudan. Annals Trop Med Parasito 75: 469-470.

\section{Your next submission with Juniper Publishers will reach you the below assets}

- Quality Editorial service

- Swift Peer Review

- Reprints availability

- E-prints Service

- Manuscript Podcast for convenient understanding

- Global attainment for your research

- Manuscript accessibility in different formats

( Pdf, E-pub, Full Text, Audio)

- Unceasing customer service

Track the below URL for one-step submission https://juniperpublishers.com/online-submission.php 